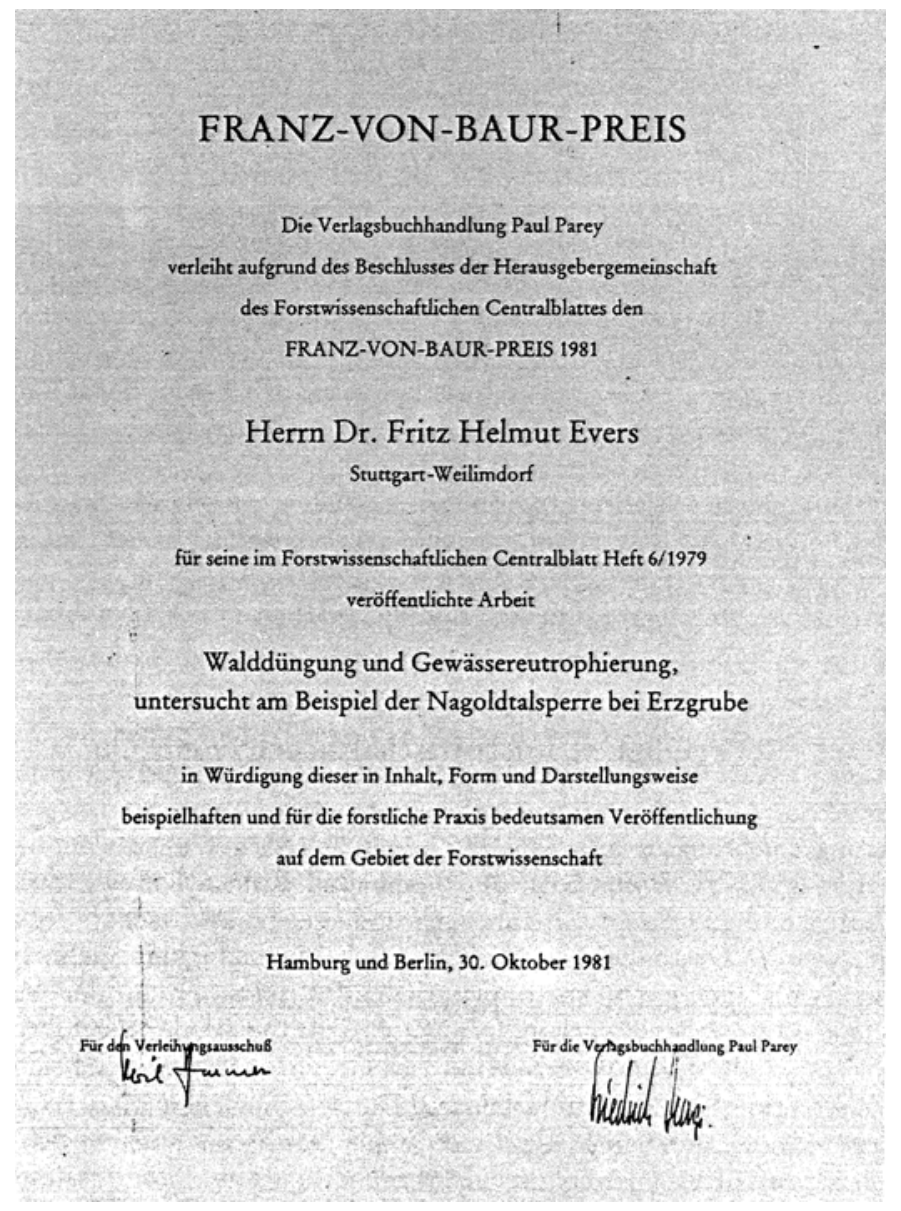

\title{
FRANZ-VON-BAUR-PREIS VERLIEHEN
}

Im Zusammenhang mit der Forstlichen Hochschulwoche in München wurde am 30. Oktober 1981 zum ersten Mal der vom Verlag Paul Parey gestiftete Franz-von-Baur-Preis verliehen. In Anwesenheit des Stifters, Dr. Dr. Friedrich Georgi, wurde die abgebildete Urkunde vom Dekan der Forstwissenschaftlichen Fakultät München, Prof. Dr. PETER Schtirt, dem Preisträger, Herrn Forstdirektor Dr. Frirz Helmut Evirs, überreiche. Die nächste Verleihung soll 1983 im Rahmen der Forstlichen Hochschulwoche in Göttingen erfolgen. 